\title{
The Prospects \& Problems Of Information Technology In The Banking Industry In Nigeria
}

\author{
Kadiri Kamoru O. \\ Electrical/Electronics Department, Federal polytechinc Offa Kwara State.Nigeria
}

\begin{abstract}
This study looks into prospects and issues of data technology within the Nigeria banking industry. Data technology has been acknowledged as a life wire of banks within the monetary sector because it promotes and facilitates the performance of banks in various countries. However, with reference to IT security in Nigeria, there's a variation within the level of trust that customers have in their banks. Most of the sampled customers responded that network is unreliable and there's an occasional shortage|of money deduction, unable to dispense, insufficient funds and alot of other vices while using ATM machine in Nigeria. They noted that IT security may be a major downside to banking in Nigeria and therefore the industry isn't stable enough for ebanking. Numerous customers were sampled from 9 totally different banks in Nigeria mistreatment accidental sampling technique and form was used as knowledge assortment instrument. Whereas four hundred and fifty (450) questionnaires were distributed to respondents, however solely three hundred and sixty (360) were retrieved. The study discovered that data technology has vital result on the bank productivity, cashiers' work, banking transactions, bank patronage, bank services delivery, client services and bank services. These have an effect on the expansion and development of the industry completely. Customers can currently withdraw money through the ATM machines in any part of the country. Customers don't have to be compelled to move regarding with huge sums of money anymore; customers also are being attended to inside the Bnking hall within a reseaonable time frame with advent of IT In the light of the above the paper advice that the ability banking sector ought to be deregulated along with the independence of the country.
\end{abstract}

Keywords: Information technology, Security, E-Banking, Banking industries, Nigeria.

\section{Introduction}

Financial systems, everywhere in the globe, play elementary roles within the development and growth of the economy. The effectiveness and potency in playing these roles, notably the intervention between the excess and deficit units of the economy, rely for the most part on the amount of development of the financial set-up [1]. during this twenty first century, the banking industries operate in an exceedingly advanced and competitive setting that's characterised by dynamical conditions and extremely unpredictable economic climate. Information Technology (IT) is at the middle of this international amendment curve of e-banking system in African country nowadays, the main players within the market area unit are the banks and discount homes. The banking industries play the intermediate role of making certain mobilization of idle funds from the excess units to the deficit sector[2].

This is a replacement era of ages everywhere in the globe, countries area unit getting down to vie and fight over management of knowledge instead of natural resources. Today, it's all concerning e-platform, this means providing monetary services through electronic media to various customers regardless of place, time and distance. In response to the stress for fast, economical and reliable services, players within the banking industries area unit progressively deploying technology as a way of generating insights into customers' behavioural patterns and preferences[3]. Well developed outsourcing support functions (technology and operations) area unit progressively being employed to supply services and manage prices e.g. cash dispenser Machine networks, Cards process, Bill presentment and Payments, package Development, centre operations and Network management [4].

Technology has become a strong force that drives the globe toward a convergency commonality[2]. Since the showtime of the human era, technology has been one in all the foremost essential and most vital ingredients that facilitate the event of grouping. [2],[3]. throughout the last 2 centuries, technological changes have usually been associated with economic process within the variety of new sorts of merchandise and services.

Despite the positive impact of technology on society, it's on the opposite hand junction rectifier to uncaused use in criminal activities like law-breaking. It has become easier to steal a penny from checking account homeowners, victimising the net than through standard bank theft [5],[6],[7]. Since banking is very supported trust from its customers, security problems can stay a special concern within the banking industries. Hence, the danger of hackers, denial of service attacks, technological failures, breach of privacy of client info and opportunities for fraud created by the obscurity of the parties to electronic transactions have to be compelled 
to be properly managed. This paper looks into IT security, the share of trust customers have within the banking industries in Nigeria, prospect in adoption of recent technology to facilitate service potency, and therefore the availableness and dependability of networks. It conjointly focuses on money, charges and withdrawal connected problems.

Although lots of analysis works has been done on the prospects and challenges of knowledge Technology within the industry, these analysis works area unit broad primarily based and solely few are literally carried on Electronic Banking (E-banking). fashionable banks currently realise that solely people who overhaul their payment service delivery and operations area unit probably to survive and prosper within the twenty first century [3,][8],[9]. This can be as a result of pressure of economic process, consolidation, privatisation, freeing and quickly dynamical technology (Connel and Saleh 2004). so as to properly place themselves in favourable positions for competitions and be one in all those firms to be reckoned with within the new century, banks area unit creating use of net to execute mobile banking, this developed from transferral PCs along to make native and Wide space Networks through client/server technology[10].

Many banks have put in fashionable laptop inter-connectivity backbone that will change them come through communications of information and transmission over Internets, Intranets and Extranets. They conjointly realised that they need to realize not solely management/staff wide laptop accomplishment however what may be known as information accomplishment i.e. knowing a way to find, analyse, store and use information. All employees and managers in an exceedingly fashionable bank have to be compelled to be able to search and gather knowledge from many sorts of sources, analyse them, choose relevant ones and organise them in such a way to permit them build choices supported the union data[11].

Banks of the longer term realises that the banking of tomorrow needs a lot of of knowledge technoology manipulations and shuffling of bits-based cash and different banking transactions, rather than paper. In different words, paper primarily based transactions area unit currently being replaced by electronicbased transactions e.g. the net. whether or not a bank would achieve success or not rely upon the extent to that it's finance in IT associate degreed victimisation in an innovative manner. This space has been tip to be a serious competitive ground for banks that area unit operative within the post-consolidation era[10],[11].

What area unit/ the main problems required to be down pat by African country banks so as to vie with the remainder of the world? What area unit/ the main developments and challenges within the Nigerian operative setting that area unit need in moving the expansion of information technology banking within the industry? These area unit brings a number of the queries that will be self-addressed within the course of this study[12],[13].

\section{Statement Of The Problem}

Information Technology banking may be a drive that's ever-changing the landscape of the banking system basically, specially, towards a a lot of competitive business. Electronic banking has blurred the boundaries between completely different money establishments, enabled new money merchandise and services, and created existing money services accessible in several packages [4],[14]. However, the influences of electronic banking go so much on the far side.

The developments in electronic banking, beside alternative money innovations, square measure perpetually transfer new challenges to finance theory and ever-changing people's understanding of the financial set-up.

It is not shocking that within the application of information technology devices for banking in Nigeria, the money establishments have to be compelled to face its issues. Communications over the net square measure insecure and sometimes full. The money establishments would even have to agitate alternative net challenges as well as security, quality of service and a few aberrations in electronic finance [15].

Besides, the prevailing business surroundings conjointly poses some challenges to the sleek operations of IT in banking in Nigeria. a number of these operational challenges embody epileptic power offer, dominance of money dealings within the economy, low level of awareness among Nigerians etc [16]. The thrust of this analysis work shall be looked at the trend of knowledge technology for banking in Nigeria and a critically examination of the challenges noted on top of it.

\section{Objectives Of The Study}

Some of the objectives, that this paper aim to realize square measure as follows: (i) to guage the prospects of banking in Nigerian banking system and money establishments (ii) to guage the impact of IT (Information Technology) in banking on the operations of monetary establishments within the country

(iii) to look at the impact of IT (Information Technology) on bank-customer relationship (iv) to hunt to look at the challenges facing the implementation of IT (Information Technology) banking in 
Nigeria

(v) to look at the final International expertise on the study.

(vi) to guage the issues of IT (Information Technology) in banking on the operations of monetary establishments within the country

\section{Research Queries And Hypotheses}

The study would supply answers to the subsequent questions:

1. will IT (Information Technology) banking contribute to the potency and responsibleness of banks and banking?

2. will IT (Information Technology) banking improves bank-customer relationship and retains them to their several banks?

3. To what extent would it not (Information Technology) banking improve the fortune of banks? 4. What square measure the results of frequent changes and upgrading of knowledge Technology equipment on the bank's profitability?

5. ought to all banks in Nigeria venture into IT (Information Technology) banking services rather continued with the normal banking?

6. What square measure technical and operations challenges facing the adoption of IT (Information Technology) banking in Nigeria?

\section{Research Hypotheses}

The following hypotheses square measure developed from the analysis queries above: 1. IT (Information Technology) banking enhances banks gain and potency. 2. IT (Information Technology) banking improves bank-customer relationship. 3. Adoption of IT (Information Technology) banking would enhance the fortune of the banks. 4. A lot of banks in Nigeria square measure wanting to be part of the bandwagon of alternative banks that gives IT (Information Technology) banking services due to the deserves concerned. 5. The Nigerian Business surroundings hinders the sleek operations of IT (Information Technology) banking within the country.

\section{Significance Of The Study}

This study is significant as a result of it might facilitate to enlighten operators within the banking sector and alternatively involved people and organisation on the prospects of IT (Information Technology) in banking. The analysis shall primarily determine the technical and operational prospects and issues facing banking in Nigerian business surroundings and suggests \{ways|ways that|ways in that by which they might be tackled.

\section{Scope Of The Study}

In pursuance of the target of the study, attention shall be targeted thereon (Information Technology) banking among alternative IT commerce implementation so as to conduct associate degree empirical investigation into the adoption of IT banking in Nigeria, this study shall examine the character IT banking operations altogether business Banks of Nigeria.

\section{Banking system in Nigeria}

It is incontrovertible that the industry is the engine of growth in any economy, given its performance of monetary intercession. With this performance, banks facilitate capital formation, lubricate the assembly engine turbines and promote economic process, [7],[10]. However, banks' ability to engender economic process and development depends on the health, soundness and stability of the system the requirement for a powerful, reliable and viable \{banking system|banking business|industry\} is underscored by the actual fact that the industry is one in every of the few sectors within which the shareholders' fund is merely atiny low proportion of the liabilities of the enterprise

Due to increasing demand for customers' deposits, Nigerian banks have realised the importance of fine and prompt client service. what is more, thanks to the actual fact that some customers lost their deposits in within the erstwhile distressed banks, customers have currently become wiser, a lot of discerning, alert and complex with regards to picking wherever it's safe to place their cash, and wherever they'd be services promptly, ideally during a pleasant, courteous and friendly surroundings. Thus, they need started staring at the extent of service and expertise of the banks before depositing their funds[17].

In Nigeria these days, proximity to the bank is not any longer the difficulty, as there square measure banks virtually all over. the difficulty is that that issues of safety and level of service, with relevance quality, speed and potency. On the part of the banks, they realised that a method within which they'll offer quality 
service is through the employment of technology. Hence, there's a growing rate of adopting new technologies in Nigerian banking operations.

Moreover, there's the growing proof that customers have started associating quality service in alduring a|in associate degree exceedingly|in a very\} bank with the bank's possession of an on-line, period system. As a matter of truth, possession of such a system is currently judged to be trigonometric function qua non of a prime quality service in Nigeria. So, for a bank to be perceived as providing prime quality service, that bank should have associate degree IT system, that it uses to deliver services to customers during a a lot of timely, friendly and tactful manner, at no further price to the purchasers.

\section{Analysis Of Methodology Approach}

The data, from the knowledge constitutes the findings, were collected from 5 banks chosen in Nigeria. These EcoBank Plc, Union Bank, Guarantee Trust Bank, Diamond Bank and Enterprise Bank.Information were obtained from the first and secondary sources, that includes; interviews, structured form, journal publications, newspapers, net facilities. Secondary information square measure accustomed to complement the first information because the primary information is a complete of 450 questionnaires that were administered to customers as they visited the banks. 360 questionnaires were retrieved, representing $77.19 \%$ of the entire distributed. Personal interviews were conducted with a number of the banks' managers associate degreed supervisors within the IT department thus on gain an appreciation of what styles of IT systems were accessible within the banks. The responses were measured with a five-point Likert-type rating scale, wherever Strongly Agree $(\mathrm{SA})=5$; Agree $(\mathrm{A})=4$; Strongly Disagree $(\mathrm{SD})=3$; Disagree $(\mathrm{D})=2$; and Neutral $(\mathrm{N})=1$. Questionnaire was used as information assortment instrument and descriptive method (use of frequency tables and charts) was adopted for analysis.

\section{Result}

The two figures below represent the gender and age of respondents. The responses on gender show that male respondents accounted for thirty eighth whereas the feminine respondents square measure sixty two. For age, majority of the respondents (42\%) square measure between 21-25 years, this can be followed by those between 16 to 20 years (35\%) and 26-30 years (18\%), while the least variety square measure people who square measure 30 years and above $(5 \%)$.

Fig 2 showing age of respondents

\section{Gender of respondents}

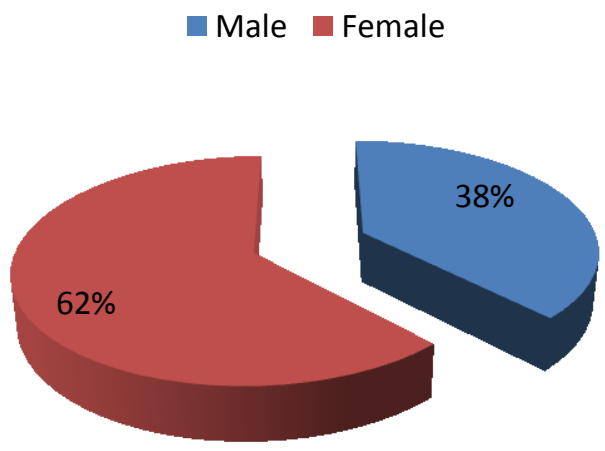

Fig 1 showing age of respondents 


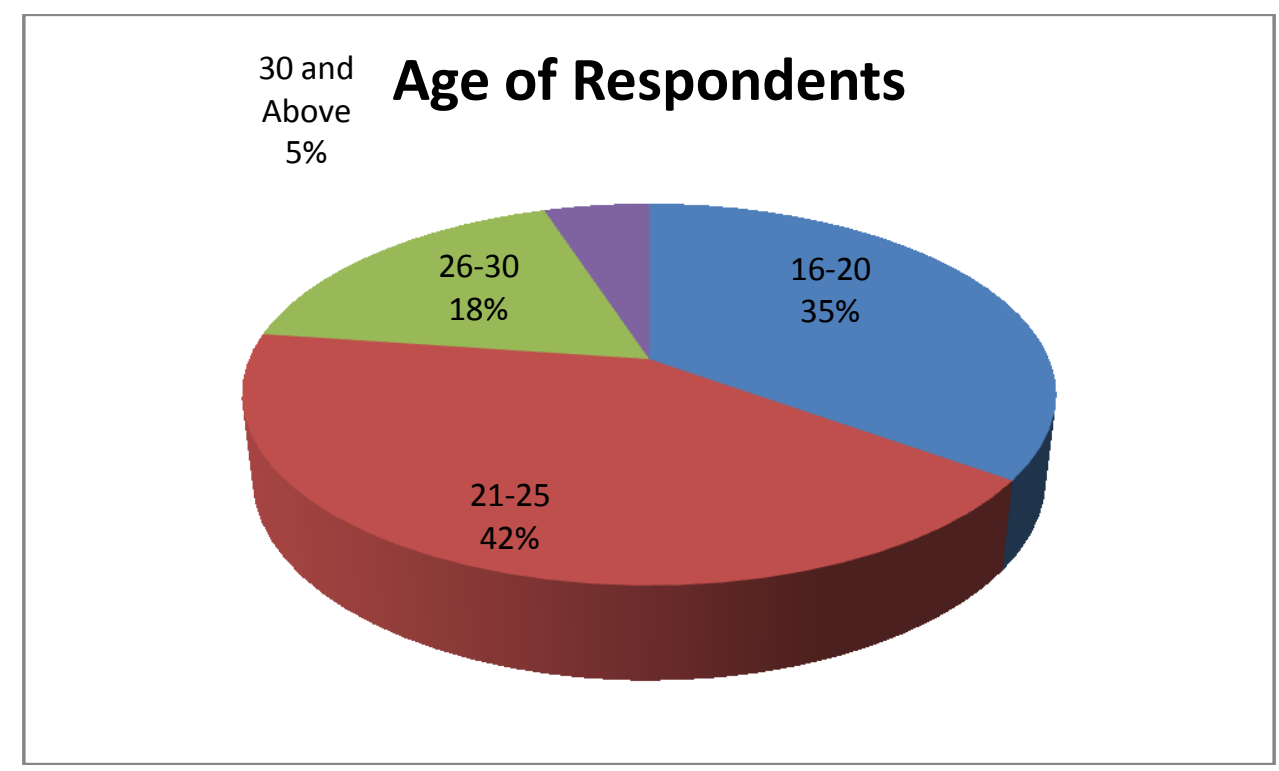

\section{Percentage of trust}

The figure below shows the amount of trust that customers in Federal Republic of Nigeria have in their banks. The ranking is as follows: 0 -20 indicates little or no, 21-40 indicates very little, 41-60 indicates average, 61-80 indicates high and 81-100 indicates terribly high. From the graph, regarding 45 of the respondents have high level of trust in their banks, and solely regarding 185 have terribly high level of trust in their banks. Also, regarding 85 have average trust whereas regarding 10 have very little trust in their banks.

Figure 3 showing Percentage of trust

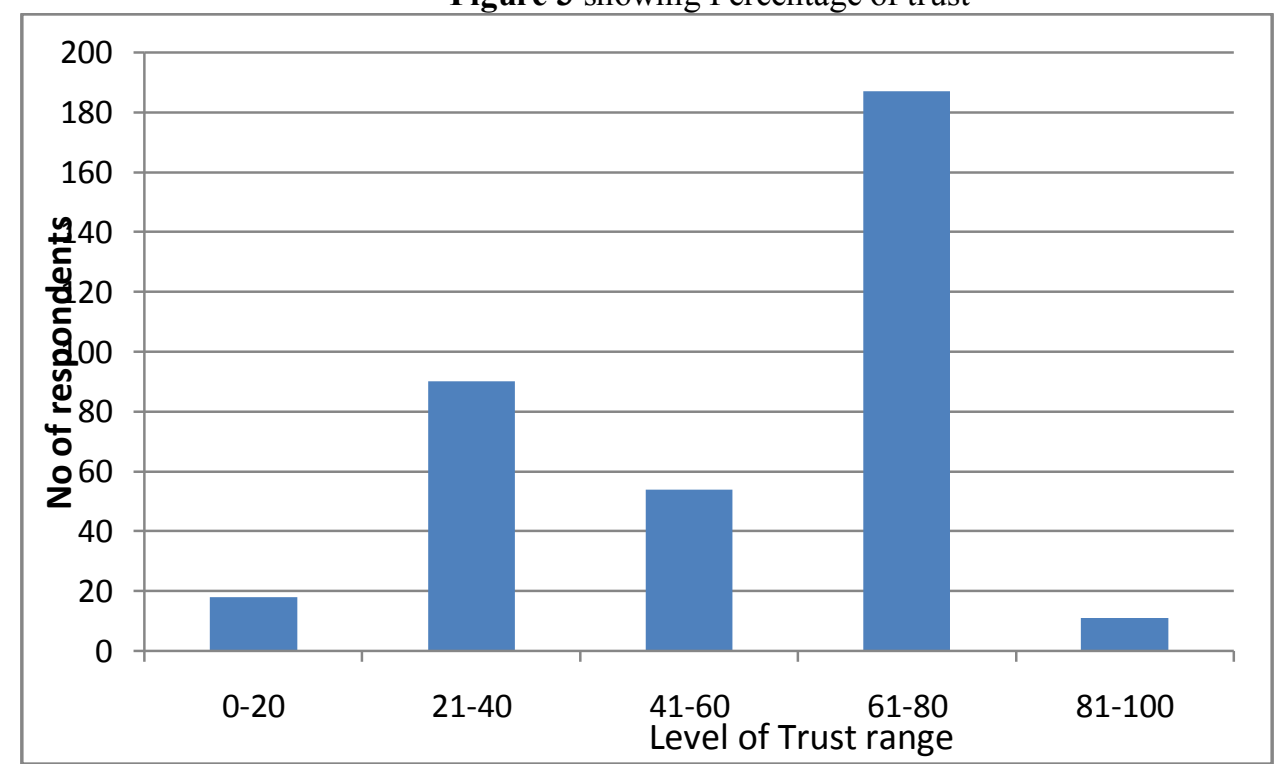

\section{Network And Different Banking-Related Problems}

The figure below shows the responses to network and different banking-related problems. although equal proportion of consumers united and disagreed on availableness of network within the banking industries in Federal Republic of Nigeria, a better proportion (about 65\%) disagreed that network is reliable. regarding eightieth united that there area unit times the ATM can create deductions from their account with none money withdrawal, whereas solely 2 hundredth united that their need had associate expertise of deceitful acts with scammers throughout mobile cash transfer. On e-banking, solely thirty five capitalize on the respondents agreed

\section{Network And Different Banking-Related Problems}

The figure below shows the responses to network and different banking-related problems. although equal proportion of consumers united and disagreed on availableness of network within the banking industries in Federal Republic of Nigeria, a better proportion (about 60\%) disagreed that network is reliable. regarding 
eightieth united that there area unit times the ATM can create eductions from their account with none money withdrawal, whereas solely 2 hundredth united that they need had associate expertise of deceitful acts with scammers throughout mobile cash transfer. On e-banking, solely four capitalize on the respondents united that the banking industry is stable enough for e-banking and regarding eighty fifth united that insecurity within the monetary establishments in Nigeria could jeopardize e-banking in Nigeria.

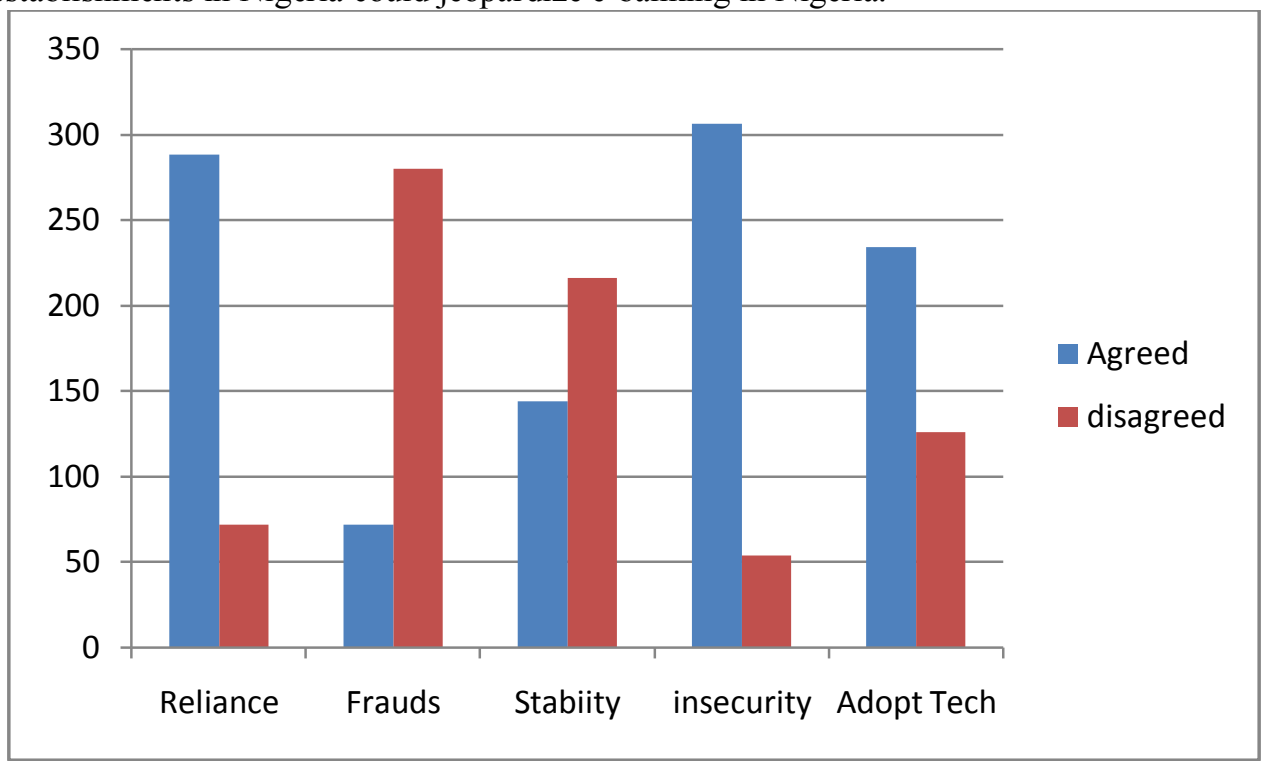

The analysis of the data collected will be descriptive in nature in the chart; it would include tabulation, frequency counts and required numbers of respondents.

Table 1: Effects of IT on banking services

$\mathrm{SA}=$ Strongly Agreed, $\mathrm{A}=$ Agreed, $\mathrm{N}=$ Neutral, $\mathrm{D}=$ Disagreed, $\mathrm{SD}=$ Strongly Disagreed

\begin{tabular}{|l|l|l|l|l|l|l|}
\hline Questions & SA & A & N & D & SD & Mean \\
\hline IT/computer is really helping this bank & 42 & 45 & 5 & 7 & 2 & 3.12 \\
\hline IT makes inquiry about the state of my account faster & 54.2 & 36.6 & 6.9 & 0 & 2.3 & 3.29 \\
\hline IT/computer has a great positive impact on the services rendered by this bank & 45 & 27. & 2 & 2 & 1 & 3.07 \\
\hline
\end{tabular}

The impact of IT on associate inquiry on a customer's state of account, and services enjoyed by the purchasers from the banks as perceived by the banks' customers, area unit shown in table one higher than $86.2 \%$ of the 360 respondents united that it absolutely was extremely serving to the banks they patronised, while $90.8 \%$ united that IT had a positive impact on the services rendered by the banks. It means that of 3.12, 3.29 and 3.07 severally for the chosen banks' respondents confirmed that it's a positive impact on the inquiry of customers' state of account and services enjoyed by the purchasers from the assorted banks.

Table 2: Effects of IT on customer services

\begin{tabular}{|l|l|l|l|l|l|l|}
\hline Question & SA & A & N & D & SD & Mean \\
\hline I don't think IT has any effect on services rendered & 5.0 & 18.8 & 9.7 & 31.9 & 34.6 & 2.77 \\
\hline There is need to improve the services rendered by this bank & 32.3 & 50.4 & 10.4 & 6.9 & 0 & 2.94 \\
\hline
\end{tabular}

Table 2; It shows the responses of clients|of consumers|of shoppers from the banks with relation to the impact of IT on customer services provided. About $66.5 \%$ disagreed that IT had no impact on the services rendered by the banks. Also, $82.7 \%$ united that there's have to be compelled to improve on the services rendered by the banks. This means that of 2.77 and 2.94 severally confirmed that it's effects on services rendered by these banks to their customers and regarding eighty three of the respondents united that the banks have to be compelled to improve on the services rendered to the purchasers. This shows that the services that the banks render presently don't seem to be the most effective they'll supply to their customers which banks ought to improve on their services.

Table 3: Promptness and efficiency of services as perceived by the customers

\begin{tabular}{|c|c|c|c|c|c|c|}
\hline Question & SA & $\mathrm{A}$ & $\mathrm{N}$ & $\mathrm{D}$ & SD & Mean \\
\hline I enjoy prompt and efficient service delivery & 36.9 & 37.7 & 9.2 & 16.2 & 0 & 2.93 \\
\hline I was once delayed in the bank because network was down & 12.4 & 32.7 & 6.9 & 31.5 & 16.5 & 2.38 \\
\hline IT does not increase prompt and efficient service delivery & 2.3 & 7.3 & 4.6 & 42.7 & 43.1 & 3.17 \\
\hline
\end{tabular}

From Table 3; Seventy fifth of the respondents united that they enjoyed prompt and economical service delivery from the banks. The mean of 2.93 shows that IT allows the banks to produce prompt and economical 
services to their customers. On the problem of delay owing to network down times, only $44.9 \%$ of the respondents united that they were once delayed within the bank as a result of network was down. The mean of 2.93 confirmed that almost all of the time, customers move to the bank once network services don't seem to be down.

Table 5: Perception of customers on the ease of conducting regular banking transactions

\begin{tabular}{|l|l|l|l|l|l|l|}
\hline Questions & SA & A & N & D & SD & Mean \\
\hline Saving or withdrawing money is time consuming & 2.7 & 31.2 & 7.3 & 36.9 & 21.9 & 2.63 \\
\hline IT eases banking transactions & 35.8 & 50.0 & 9.6 & 2.3 & 2.3 & 3.10 \\
\hline
\end{tabular}

Table 5; It shows that $58.8 \%$ of consumers disagreed that savings and withdrawal of cash is time intense. Also, $85.5 \%$ united that IT eases banking transactions. The mean of 2.63 shows that a number of the respondents united that saving and withdrawal of cash is time intense despite the employment of IT in those banks. Impacts of information technology on the interaction between cashiers and customers

Table 6: Impacts of IT on the interaction between cashiers and customers

\begin{tabular}{|l|l|l|l|l|l|l|l|}
\hline Questions & SA & A & N & D & SD & Mean \\
\hline IT has reduced the interaction between cashiers and customers & 9.6 & 27.3 & 17.7 & 30.4 & 15.0 & 2.15 \\
\hline
\end{tabular}

Table 6 shows that $36.9 \%$ of the respondents united with the read that it's reduced the interaction between cashiers and customers, $17.7 \%$ area unit indifferent to the question whereas $45.4 \%$ disagreed with the read, with a mean of 2.15 .

Table 7: Effects of IT on cashiers' work

\begin{tabular}{|l|l|l|l|l|l|l|}
\hline Question & SA & A & N & D & SD & Mean \\
\hline Computers really speed up cashier work & 45.8 & 37.3 & 6.9 & 7.3 & 2.7 & 3.12 \\
\hline
\end{tabular}

The rates cashiers within the banks attend to customers rely on the instrumentation on the market for the cashier to figure with. From table seven higher than, 83.1\% united that Personal Computer (PC) hastens cashiers' work, whereas 100 percent disagreed and $6.9 \%$ area unit indifferent. The mean of 3.12 confirmed that IT/computer extremely have an effect on the rates at which cashiers attend to customers. Generally, the employment of electronic devices like computers can go a protracted thanks to increase the speed of the cashiers' work

Table 8: IT and productivity of the banks

\begin{tabular}{|l|l|l|l|l|l|l|}
\hline Question & SA & A & N & D & SD & Mean \\
\hline IT increases banks' productivity & 44.2 & 37.3 & 13.8 & 4.6 & 0 & 2.98 \\
\hline
\end{tabular}

From table eight higher than, $81.5 \%$ of the respondents united that the employment of IT will increase bank productivity inline with the employment of IT, the bank will attend to lots of consumers since IT hastens cashiers' work. The mean of 2.98 shows that it's a positive impact on the expansion and productivity of the banks.

\section{Conclusion}

This study shows that regarding $1 / 5$ of the sampled customers have very little trust in the Federal Republic of Nigeria banks whereas $1 / 4$ area unit at the common level of trust (neither high nor low). The study shows additional that one among the foremost doubtless reasons for this variation is network dependableness within the banking system. Most of the sampled customers responded that the banking sector operates with associate unreliable network. Another doubtless reason for the variation within the level of trust, as discovered from the study, is money deduction from account with none money withdrawal with exploitation using ATM. This can be a standard observation among customers of varied banks in Federal Republic of Nigeria. It's not a surprise that almost all sampled customers complain that Federal Republic of Nigeria banking industry isn't stable enough for e-banking and insecurity within the monetary establishments may be a major obstacle to electronic banking. Obviously, the banking industries in Federal Republic of Nigeria have a lot of responsibilities on their shoulders as much as info technology security and e-banking area unit involved within the sector. It specifically thought of the perceptions of bank customers on the impact of knowledge technology on the banks. The study unconcealed that info technology has vital impact on the bank productivity, cashiers' work, banking transactions, bank patronage, bank services delivery, client services and bank services.

\section{Recommendation}

The drawback of epileptic power offer still remains a serious problem to any or all company organization in Federal Republic of Nigeria. it's counseled that the facility sector ought to be deregulated. this may promote the long anticipated adequate power offer within the country. 


\section{References}

[1]. E. J. Ofanson (PhD); O. M. Aigbokhaevbolo (PhD) and G. O. Enabulu (2010). The financial system in Nigeria: An overview of banking sector reforms. AAU JMS Vol. 1, No. 1, December 2010.

[2]. Harold, B. \& Jeff, L. (1995): 'Don’t Let Technology Pass You By', ABA Banking Journal, Box 986, Omaha, NE, p.73

[3]. Muyiwa O., Tunmibi S., and John-Dewole A.T., (2013). Impact of cashless economy in Nigeria. Greener Journal of Internet, Information and Communication Systems. Vol. 1 (2), pp. 040-043, April 2013.

[4]. Woherem, E. W. (2000): Information Technology in the Nigerian Banking Industry, Spectrum, Ibadan.

[5]. Agboola, A. A. (2006). Electronic Payment Systems and Tele-banking Services in Nigeria, Journal of Internet

[6]. Banking and Commerce, Vol. 11, No. 3, online source:http://www.arraydev.com/commerce/jibc.

[7]. Ebenezer Ankrah (2012). Technology and service quality in the banking industry in Ghana. Information and knowledge management. Vol. 2, No. 8, 2012.

[8]. Adelman, C. (2000): A Parallel Post-secondary Universe: The Certification System in Information Technology. Washington, D.C.: U.S. Department of Education

[9]. Adeyemi K. S ( 2006 ): Banking Sector Consolidation in Nigeria: Issues and Challenges

[10]. Alu, A. O (2002): Effects of Information Technology on Customer Services in the Banking Industry in Nigeria, M.B.A. Dissertation in Management and Accounting, O. A. U., Ife.

[11]. Ige, O. (1995): Information Technology in a deregulated Telecommunications Environment,Keynote address, INFOTECH 95. First International Conference on Information Technology Management, Lagos, November 16-17.

[12]. Levitt, T. (1992): The Globalization of Markets, in Transnational Management: Text, Cases and Readings in Cross-Border Management. Richard D. Irwin.

[13]. Ugwu, L. O. (1999): Assessment of Impacts of Information Technology on Selected Services Industries in South Western Nigeria, MSc Dissertation in Technology Management, O.A.U., Ife, Nigeria.

[14]. http://www.transcampus.org/JORINDV8Dec2010/JournalsV8NO2Dec201031.html

[15]. Agbada A. O. (2008) Electronic Banking in Nigeria, Problems and Prospects From The Customers' Perspective. Central Bank of Nigeria Bullion. 32(4), pp. 19-22.

[16]. Opara B. C., Olotu A. O. and Maclayton D. W. (2010) Analysis of Impact of Technology on Relationship Marketing Orientation and Bank Performance. European Journal of Scientific Research. Vol. 45(2), pp. 291-300.

[17]. https://www.facebook.com/kanospoly/posts/640312039327877?stream ref $=10$ 